\title{
Review of Survey activities 2011
}

Edited by

Ole Bennike, Adam A. Garde and W. Stuart Watt 


\section{Geological Survey of Denmark and Greenland Bulletin 26}

\section{Keywords}

Geological Survey of Denmark and Greenland, survey organisations, current research, Denmark, Greenland.

\section{Cover photographs from left to right}

1. Retrieving a sediment core in Sermilik fjord, South-East Greenland. Photograph: Robert S. Fausto.

2. Field work in Vietnam. Photograph: Flemming Larsen.

3. This Danish beech forest on Fyn was farm land during the Iron Age. Photograph: Ole Bennike.

4. Small-scale miners in Nigeria. Worldwide, c. 100 million people depend on small-scale mining. Photograph: John Tychsen.

\section{Frontispiece: facing page}

In the summer of 2011, GEUS carried out extensive reconnaissance work in South-East Greenland. The aim is to assess the mineral potential of the region, which is one of the least known regions of Greenland. The geologist is panning stream sediments in order to separate heavy minerals, possibly including gold. Photograph: Jakob Lautrup.

Chief editor of this series: Adam A. Garde

Editorial board of this series: John A. Korstgård, Department of Geoscience, Aarhus University; Minik Rosing, Geological Museum, University of Copenhagen; Finn Surlyk, Department of Geography and Geology, University of Copenhagen

Scientific editors: Ole Bennike, Adam A. Garde and W. Stuart Watt

Editorial secretaries: Jane Holst and Esben W. Glendal

Referees: (numbers refer to first page of reviewed article): Johanna Anjar, SE (29); Anonymous (65), Niels Balling, DK (41); Stefan Bernstein, DK (57); Albertas Bitinas, LT (29); Lars Ole Boldreel, DK (81); Henrik Breuning, DK (85); Gregers Dam, DK (61); Margaret Dolan, NO (25); Ida Fabricius, DK (9); Tomas Feseker, DE (69); Kerstin Geitner, DK (25); Lawrence Gill, DK (65); Sam Holloway, UK (45); Michael Houmark-Nielsen, DK (17); Shfaqat Abbas Khan, DK (41); Poul-Henrik Larsen, DK (61); James Lawrence, UK (33); Clive Mitchell, UK (85); Farrokh Nadim, NO (33); Thomas Pape, DE (69); Heikki Papunen, FI (53); Asger Ken Pedersen, DK (57); Gunver Krarup Pedersen, DK (9); Stefan Piasecki, DK (13); Hans Plaat, NL (45); Manuel Pubellier, FR (81); Jan Audun Rasmussen, DK (13); Anders Schomacker, NO (17); Inga Sørensen, DK (37); Jette Sørensen, DK (37); Mathilde B. Sørensen, NO (77); Henrik Stendal, GL (53); Kristian Syberg, DK

(49); Matti Tarvainen, FI (77); Henry Vallius, FI (21); Karen Vilholth, LK (49); Michiel van den Broecke, NL (73); Roy H. Wilkens, USA

(21); Jacob Clement Yde, NO (73).

Illustrations: Stefan Sølberg, Jette Halskov, Willy Weng, Frants v. Platen-Hallermund and Benny M. Schark

Layout and graphic production: Kristian Rasmussen

Printers: Rosendahls-Schultz Grafisk A/S, Albertslund, Denmark

Manuscripts received: 6 January 2012 - 8 May 2012

Final versions approved: 13 February 2012 - 23 May 2012

Printed: 10 July 2012

ISSN 1604-8156

ISBN 978-87-7871-339-1

\section{Citation of the name of this series}

It is recommended that the name of this series is cited in full, viz. Geological Survey of Denmark and Greenland Bulletin. If abbreviation of the name of this volume is necessary, the following form is suggested: Geol. Surv. Den. Green. Bull.26, 88 pp.

\section{Available from}

Geological Survey of Denmark and Greenland (GEUS)

Øster Voldgade 10, DK-1350 Copenhagen K, Denmark

Phone: +45 381420 00, fax: +45381420 50, e-mail: geus@geus.dk. See alsowww.geus.dk/publications/bull

\section{(C) De Nationale Geologiske Undersøgelser for Danmark og Grønland (GEUS) 2012}

For the full text of the GEUS copyright clause, please refer to www.geus.dk/publications/bull 


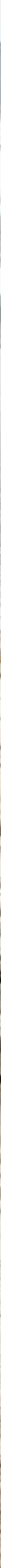




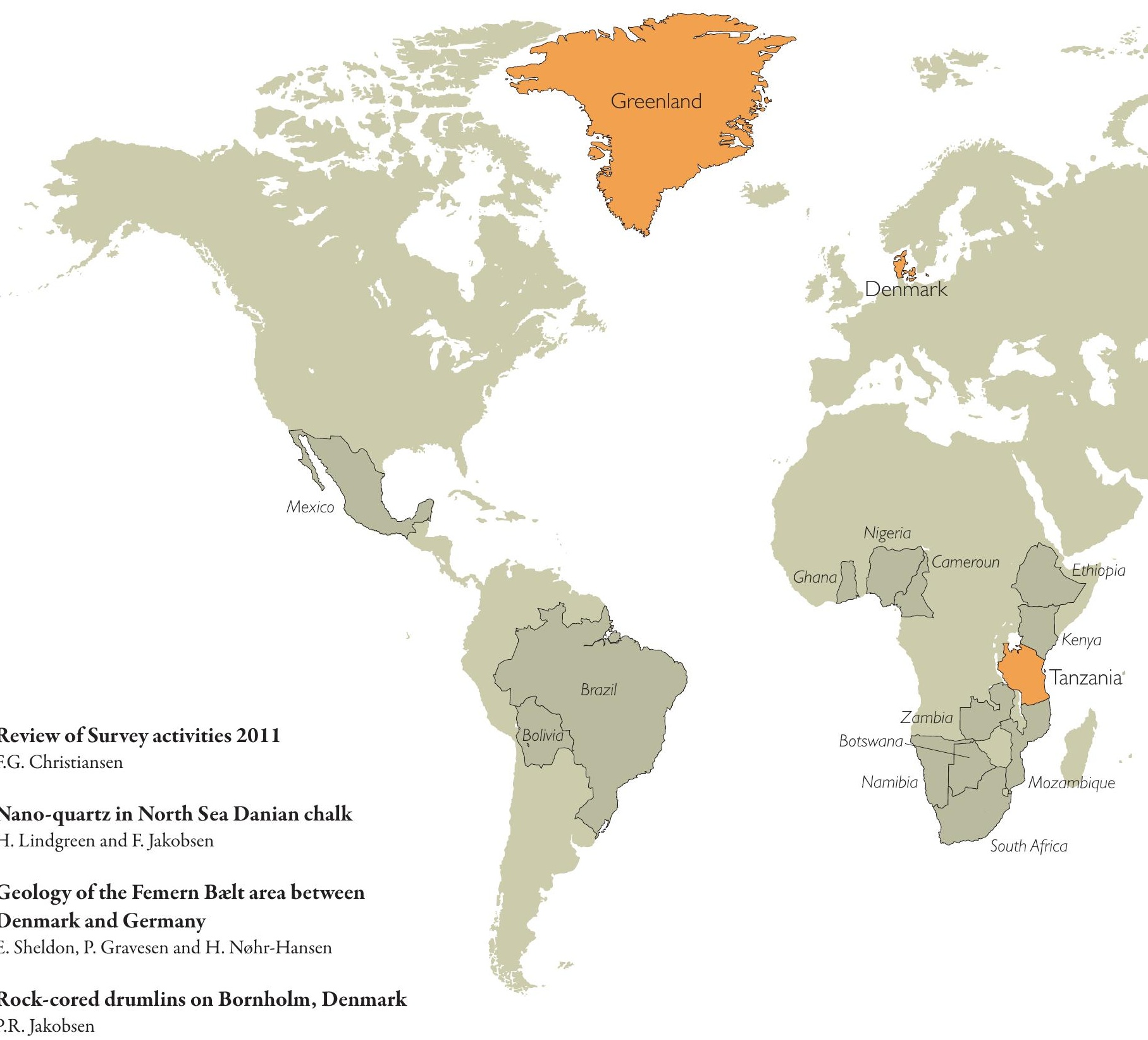

21 Methane distribution in Holocene marine sediments in the Bornholm Basin, southern Scandinavia J.B. Jensen and R. Endler

25 Natura 2000 habitat mapping in Kattegat, Denmark: an example from Lasø Trindel Z.K. Al-Hamdani and L.G. Addington

29 Early Holocene sea-level changes in Øresund, southern Scandinavia

O. Bennike, M.S. Andreasen, J.B. Jensen, M. Moros and N. Noe-Nygaard

33 Cliff collapse at Stevns Klint, south-east Denmark S.A.S. Pedersen and T. Damholt

37 Shallow geothermal energy in Denmark

T. Vangkilde-Pedersen, C. Ditlefsen and A.L. Højberg

41 Efforts to include geological and geodetic observations in the assessment of earthquake activity in Denmark

S. Gregersen and P.H. Voss

45 Results of monitoring groundwater above the natural gas underground storage at Stenlille, Denmark T. Laier

49 Groundwater protection in Denmark and the role of water supply companies

J.D. Petersen and L.F. Jørgensen 



\title{
Review of Survey activities 2011
}

\author{
Flemming G. Christiansen \\ Deputy Director
}

2011 was a good year for the Geological Survey of Denmark and Greenland (GEUS) with fruitful discussions of strategies, handling of challenges posed to our society that has strong needs for growth and investments, and consequently for developing new projects for the future within the many fields where GEUS is involved.

GEUS has been through a long - but very constructive - process of putting together a new strategy that reflects the changes in society and new demands from many different stakeholders. This new strategy, 'Geology for society knowledge for growth and welfare', covers the period up to 2020 and is based on an analysis of key driving forces such as transition from fossil fuel to sustainable energy, adaptation to changing climate conditions, need for water resources locally and globally, and international competition for critical minerals. The strategy includes a number of specific strategic topics. As these topics have been discussed between scientists and management over a long period and in some cases are related to new and on-going Survey projects, these topics are reflected in many of the papers in this year's issue of Review of Survey activities.

The reader will find contributions covering several of our new strategic topics such as: 'Past and future climate', 'Geology across land and sea', 'Geology in the public arena', 'Water resources under pressure', 'Oil and gas supply and transition to green energy' and 'Geothermal energy and heat storage', as well as papers on other subjects from GEUS' very broad project portfolio. Some of them describe specific, short projects, and others focus on results from some of our long-term monitoring projects on for example groundwater, gas storage, ice and earthquakes.

GEUS' activities and research in Denmark cover many different subjects such as fossil fuel and renewable energy, water, climate history and monitoring and adaptation to climate changes, nature protection, input to large infrastructure projects and data management.

Chalk is the main oil reservoir in the Danish part of the North Sea and understanding its mineralogy and diagenesis has crucial implications for production parameters. One paper proposes a new model for the formation of flint from studies of nano-quartz.
As part of planning the fixed link across Femern Bælt between Denmark and Germany, GEUS has been involved in geological and geotechnical investigations. Results of a multidisciplinary biostratigraphic study of pre-Quaternary deposits (especially Paleocene and Eocene) are summarised here.

Although the surface morphology of Denmark is well mapped and described in detail, there is still room for new observations and reinterpretation of some glacially formed features like rock-cored drumlins from Bornholm that are described for the first time.

Understanding methane distribution in young marine sediments is important for long-term use and protection of areas such as the Baltic Sea. GEUS has been partner in the Baltic Gas project with a key role to map the occurrence of free gas, to quantify the flux of gas and to study the processes and parameters governing methane generation and consumption. Natura 2000 is a network of nature protection areas under the Habitats Directive of the European Union. Some results from mapping of a Natura 2000 area with bubbling reefs in the inner Danish waters are presented in this volume. Another paper describes how Øresund became a strait between 8000 and 9000 years ago due to sea-level rise after an earlier history of being dry land with some bogs and lakes, and later a fjord.

The coastal cliff Stevns Klint is a classical locality for field trips, especially for studying the world's best exposed Cretaceous-Tertiary boundary, but also for the beautiful scenery. For this reason an understanding of the risks of cliff collapse is crucial, and an analysis of the different collapse types including volumetric considerations based on photogrammetric studies is given in one of the papers.

With a strong Danish ambition to reduce the dependence on fossil fuel by using renewable energy sources, shallow geothermal energy can be economically competitive. One paper introduces this concept with comments on exploitation, modelling and groundwater protection. The latter is very important in Denmark where almost all drinking water comes from groundwater. The Danish policy on this topic and the role of the authorities and water supply companies are discussed. GEUS is also involved in long-term monitor- 
ing of groundwater above the gas storage facility at Stenlille on Sjælland. There has been no evidence of leakage through the geological barriers, and only one short incident with traces of gas from an injection well. Earthquake activity is low in an intra-plate region like Denmark, but prediction of seismicity is important, and the question whether geological and geodetic observations should be included in the assessment is discussed.

In 2011 there was a high level of field activities in Greenland with a major mapping and geochemical programme in South-East Greenland, a large field and shallow-core drilling programme of poorly known Cretaceous sediments in North-East Greenland and the EAGER cruise offshore North-East Greenland, which was part of the Danish Continental Shelf Project. Results from these large projects will be presented later; in this issue results from other completed and on-going projects are presented.

This volume also contains a discussion of the possibility to use anorthosite from Greenland as a future raw material for aluminium instead of bauxite. Based on regional knowledge and geochemical data, it is suggested that the Fiskenæsset complex is especially interesting. 3D mapping and modelling is high on the agenda in the new GEUS strategy in both Denmark and Greenland. Different methods are used in the crystalline areas of Greenland, for sedimentary basins or for Quaternary deposits in Denmark. A case study from the Skaergaard intrusion in southern East Greenland is presented.

In Greenland, the Bureau of Minerals and Petroleum in Nuuk is preparing licensing rounds offshore North-East
Greenland for 2012 and 2013, and part of the regional preparation for this work is described. There is a high level of exploration activities throughout the West Greenland shelf in these years, and one paper brings a case study of bitumen from crystalline rocks in South Greenland.

Climate models predict a marked warming in the Arctic that may lead to the release of large amounts of methane bound in permafrost areas or in gas hydrates. The background of and some preliminary results from a scientific cruise to Disko Bugt in 2011 are related. The important monitoring programme of the Greenland Ice Sheet (PROMICE) continues to develop, and a paper summarises the results of ablation observations from 2008 to 2011. GEUS takes part in operating many seismic stations in Denmark (5) and Greenland (18), and it is very time-consuming to analyse all data manually. Test of an automatic method is described in another paper, and although the method is efficient, manual processing is still required to detect all earthquakes and for quality control purposes.

GEUS works in many different countries with many different types of projects. The last two papers in this issue are about Vietnam and Tanzania. GEUS has been active in Vietnam together with our sister organisation Vietnam Petroleum Institute and universities in Hanoi for almost twenty years. In Tanzania a Geocenter Denmark project has studied the possibilities of restoring soil fertility by using locally quarried rock phosphate and lime. 